\title{
NANOFIBRILLATED CELLULOSE, THE SMALL PROMISING FIBER: CHARACTERISTICS AND POTENTIALITIES
}

\author{
Eliane Lopes da Silva ${ }^{1 *}$, Helena Cristina Vieira ${ }^{1}$, Joielan Xipaia dos Santos ${ }^{1}$, Silvana Nisgoski ${ }^{1}$, Cyro Ketzer \\ Saul $^{2}$, Graciela Inés Bolzon de Muñiz ${ }^{1}$
}

\author{
${ }^{1}$ Federal University of Paraná - Department of Forestry Engineering and Technology- Curitiba, PR, Brazil. \\ eliane0103@gmail.com*, lenacristin@gmail.com, joilan87xipaya@gmail.com, silvana.ufpr@gmail.com, graciela.ufpr@gmail.com \\ ${ }^{2}$ Federal University of Paraná - Department of Engineering and Materials Science - Curitiba, PR, Brazil. \\ cyro.saul@gmail.com
}

Recebido para publicação: 11/04/2018 - Aceito para publicação: 03/08/2018

\begin{abstract}
Resumo
Celulose nanofibrilada, a pequena fibra promissora: características e potencialidades. Celulose, um material vegetal, abundante, biodegradável, renovável e disponível no mundo todo, a partir da qual se extrai a celulose nanofibrilada, uma suspensão homogênea de fibras com diâmetros nanométricos. É possível que a celulose nanofibrilada substitua no todo ou parcialmente outros materiais, uma vez que suas propriedades físicas possibilitam tal aplicação. O conhecimento de suas caraterísticas e propriedades são importantes na compreensão de seu comportamento em diversas aplicações. Com isso, os objetivos deste trabalho foram extrair a nanocelulose a partir de polpa branqueada de eucalipto, via processamento mecânico por moagem, e caracterizar a celulose nanofibrilada obtida, comparando-as. A celulose nanofibrilada apresentou aparência bem distinta em relação à polpa celulósica de partida, quando em mesma concentração, demonstrando maior poder de absorção de água e entrelaçamento fibrilar. O material nanofibrilado apresentou respostas diferentes em relação ao material de partida quanto às dimensões, estabilidade térmica, cristalinidade, viscosidade e grau de polimerização. A celulose nanofibrilada possui a mesma composição química por infravermelho, diâmetros menores, da ordem de 21,7 nm em relação aos $11,4 \mu \mathrm{m}$ da celulose. A celulose nanofibrilada apresenta, também, menor resistência térmica, cuja temperatura de degradação foi cerca de $20{ }^{\circ} \mathrm{C}$ menor que a da polpa celulósica de partida e, teve seu índice de cristalinidade diminuído. Quanto à viscosidade e grau de polimerização, houve queda de $25 \%$ em comparação ao material de partida. Os resultados aqui apresentados indicam que a celulose nanofibrilada mostra-se diferenciada em relação à polpa celulósica de partida o que sugere sua aplicação como alternativa a materiais já existentes.

Palavras-chave: nanocelulose; desfibrilação mecânica; caracterização.
\end{abstract}

\begin{abstract}
Cellulose: an abundant, biodegradable and renewable plant material that is available all around the globe, from which nanofibrillated cellulose (a homogeneous suspension of fibers with nanometer-scale diameters) can be extracted. The nanofibrillated cellulose, in what concerns its range of application, may completely or partially replace other materials due to its particular physical properties. Knowing its characteristics and properties is important in understanding its behavior in various applications. In light of this remarks, the objective of this research was to extract the nanocellulose from bleached eucalyptus pulp through mechanical milling to characterize the resulting nanofibrillated cellulose and compare both. The nanofibrillated cellulose presented a very distinct appearance in relation to the original cellulose pulp when they were analysed in the same concentrations, demonstrating greater water absorption and fibrillar interweaving. The nanofibrillated material showed different responses in comparison to the original in terms of dimensions, thermal stability, crystallinity, viscosity, and degree of polymerization. The nanofibrillated cellulose displays the same chemical composition through infrared analysis and has diameters of around $21.7 \mathrm{~nm}$, smaller than the cellulose diameter of $11.4 \mu \mathrm{m}$. The nanofibrillated cellulose also exhibits lower thermal resistance: its decomposition temperature was about $20{ }^{\circ} \mathrm{C}$ lower than that of the original cellulose pulp, and its crystallinity index has decreased. As for viscosity and degree of polymerization, there was reduction of $25 \%$ compared to the original material. The results presented hereby indicate that the nanofibrillated cellulose has unique features in relation to the original cellulose pulp, which supports its application as an alternative to existing materials.
\end{abstract}

Keywords: Nanocellulose, mechanical defibrillation, characterization.

FLORESTA, Curitiba, PR, v. 49, n. 3, p. 411 - 420, jul/set 2019.

Silva, E. L. et.al.

ISSN eletrônico 1982-4688 


\section{INTRODUCTION}

Nanofibrillated cellulose (NFC) exhibits attractive properties such as large surface area, high aspect ratio, low thermal expansion, non-abrasive nature and non-toxic character. It also has the ability to act as a significant reinforcement even at low loading levels, being used as a reinforcing agent in polymer nanocomposites. Nanocellulose-based materials are by nature environmentally friendly, carbon neutral, non-toxic, sustainable and recyclable. Thus, they have potential to be classified as green nanocomposite materials, with many favorable and unexplored characteristics.

In addition, NFC has great potential application in various industrial segments, such as textiles, regenerative medicine, tissue engineering, catalysis, surface coatings, drug delivery, food packaging and nanocomposite materials (CORREIA, et al., 2016; DEEPA et al., 2015; KHALIL et al., 2014; SACUI et al., 2014; LAVOINE et al., 2014). It can impact different fields not only due to its peculiarities, but also because it is very light, resistant, cheap, renewable, biodegradable and environmentally friendly (SOUZA et al., 2016; SOUZA et al., 2010). Apart from being manufactured from the cellulose pulp, this material may also be prepared from branches or even wood processing residues, which are transformed in materials of higher added value (DEEPA $e t$ al., 2015). Nanofibrillated cellulose may even substitute in great measure most of the plastic (SABA et al., 2014), since its physical properties enable its application in composite materials. Composite materials with natural fibers are used in the automotive industry, for example, due to an overall weight reduction, which increases efficiency and consequently reduces engine emissions (MOON et al., 2016).

The mechanical treatment - through which NFC can be obtained - may be classified as mechanical defibrillation with high shear forces, microfluidization, and ultrasonication, resulting in a material composed of micro and nanofibrils. During the mechanical defibrillation process, the structure of the fiber, composed of multiple layers of nanofibrils bound by hydrogen bonding, is defibrillated by high shear forces generated by friction inside the equipment (CORREIA et al., 2016; LAVOINE et al., 2014; VILLANOVA et al., 2011, KALIA et al., 2014). Micro and nanofibrils of cellulose have many industrial applications, such as pharmaceuticals (VILLANOVA et al., 2011), diet foods (OKIYAMA et al., 1993), packaging and films (SYVERUD et al., 2011), and special papers (SEHAQUI et al., 2011), in addition to being used especially as a reinforcing agent in polymer matrices (KALIA et al., 2014).

The interaction and compatibility between the polymer and cellulose raw materials are essential for industrial applications as well as for the processing and quality of the final products (TONOLI et al., 2012). The morphological properties of nanocellulose structures, such as shape, length and diameter, depend mainly on the extraction process used and on the origin of the cellulose raw material (KALIA et al 2014).

The present research aims at the production and at the comparative characterization of both the nanofibrillated cellulose produced through mechanical defibrillation with high shear forces and the original cellulose pulp, in order to understand the differences between both.

\section{MATERIAL AND METHODS} sources.

In this study, we used bleached cellulose kraft pulp of Eucalyptus sp. (Kappa 2.0) from commercial

\section{Preparation of nanofibrillated cellulose via mechanical defibrillation}

The pulp was initially hydrated in water and went through a degradation treatment by using a mixer. Then, it went through a mechanical defibrillation treatment in the Supermasscolloider Masuko Sangyo (MKCA6-3Masuko Sangyo Co., Ltd.) grinder. The samples of cellulose material were suspended in distilled water at concentration of $1.5 \%$ on a dry basis. Grinder settings were 1500 RPM, distance between discs of $0.1 \mathrm{~mm}$ and total number of 10 passes, based on the literature (KALIA et al., 2014). The resulting material was then designated Nanofibrillated Cellulose (NFC). During the sample processing, portions that had undergone 1, 3, 5, 8 and 10 passes through the grinder were separated, in order to evaluate viscosity, degree of polymerization (DP) and crystallinity of the cellulose during the process.

\section{Morphological characterization}

Scanning Electron Microscopy (SEM)

The images for the visualization of the structures and dimensions of the original fibers were obtained in a Tabletop Hitachi TM-1000 Scanning Electron Microscope. Measurements of 25 fiber dimensions were made, adapted from Muñiz and Coradim (1992). The images were processed with the Gwyddion 2.48 (Czech Metrology Institute) Open Source software. 


\section{Atomic Force Microscopy (AFM)}

The topographic image of the NFC was obtained through Atomic Force Microscopy, non-contact mode, in an Agilent 5500 Scanning Probe Microscope equipment and PicoView imaging software. The characteristics of the tip are: monolithic silicon AFM probe - Model: TAP190AL-G (Budgetsensors), with Force Constant of 48 N/m; Resonant Frequency of $190 \mathrm{kHz}$; Length of $225 \mu \mathrm{m}$; Width of $38 \mu \mathrm{m}$ and Thickness of $7 \mu \mathrm{m}$. The sample was diluted in water to an approximate concentration of $0.03 \mathrm{mg} / \mathrm{mL}$. Three drops of this solution were deposited on a surface made of Mica and air dried before proceeding for analysis. The images were processed with the Gwyddion 2.48 (Czech Metrology Institute) Open Source software.

Transmission Electron Microscopy (TEM)

The evaluation of the structure and dimensions of the NFC was done using a Transmission Electron Microscope JEOL - JEM 1200EX-II - with resolution of $0.5 \mathrm{~nm}$, magnification range of up to $600 \mathrm{kx}$ and voltage of up to $120 \mathrm{kV}$, equipped with a CCD Gatan (Orius SC1000B) high resolution camera.

The NFC sample was prepared by dilution in water to an approximate concentration of $0.03 \mathrm{mg} / \mathrm{mL}$. A drop of this solution was deposited on the sample holder, which consists of a nitrocellulose film-coated grill with grid size of 200 mesh. This sample holder was dried in a vacuum desiccator with silica as the desiccant at room temperature. After drying, the holder with the sample was taken to the imaging equipment. The images were processed with the Gwyddion 2.48 (Czech Metrology Institute) Open Source software.

\section{Chemical and Thermal Characterization}

Fourier transform infrared spectroscopy (FTIR)

Mid-infrared spectra were obtained in a Bruker model Tensor 37 spectrometer using films (produced by solution casting method) directly on the support. Measurements were performed between 4000 and $400 \mathrm{~cm}^{-1}$ in transmission mode with an accumulation of 64 scans and nominal resolution of $4 \mathrm{~cm}^{-1}$.

Thermogravimetric analysis (TGA)

The equipment used was the Setaram Setsys Evolution TGA-DTA/DSC 1500. The test was carried out using an Alumina crucible. The conditions of analysis were: Argon purge rate of $20 \mathrm{~mL} / \mathrm{min}$, constant temperature at $30{ }^{\circ} \mathrm{C}$ for $10 \mathrm{~min}$ (stabilization), heating from $30{ }^{\circ} \mathrm{C}$ to $650{ }^{\circ} \mathrm{C}$ at a rate of $10{ }^{\circ} \mathrm{C} / \mathrm{min}$ (thermal analysis) and cooling from $650{ }^{\circ} \mathrm{C}$ to $30^{\circ} \mathrm{C}$ at a rate of $30^{\circ} \mathrm{C} / \mathrm{min}$ (finalization). Data on mass loss (thermogram) were acquired in the thermoanalysis stage. The bleached pulp samples were grouped in fiber bundles and the NFC samples were prepared over films obtained from solution casting and cut into small pieces of approximately $1 \mathrm{~mm}^{2}$.

\section{Rheological Characterization and Crystallinity}

Viscosity and Degree of Polymerization (DP)

Viscosity establishes a relationship between the DP of the chains and the level of cellulose degradation due to the mechanical defibrillation process. The determination of the viscosity and DP of both the cellulose pulp and the NFC suspensions followed the ASTM D4243 Active Standard (ASTM INTERNATIONAL, 2009). A 1\% cupric ethylenediamine (EDC) solution was used as solvent and a capillary viscometer was used for measurements, according to the same Standard. Two samples from each cellulose treatment step $(0,1,3,5,8$ and 10 grinder passes) were used to evaluate the effect of the mechanical treatment on the viscosity and on the DP of the sample.

The specific viscosity $\left(\eta_{\mathrm{s}}\right)$ was transformed into intrinsic viscosity by using Martin equation. After that, the Mark-Houwink-Sakurada equation was used to transform the intrinsic viscosity data into the viscometric degree of polymerization.

$$
\eta_{s}=[\eta] \cdot c \cdot 10^{k[\eta] c}
$$

In which: $\eta_{\mathrm{s}}$ : specific viscosity; $\left.\eta\right]$ : intrinsic viscosity, $c$ : cellulose concentration (dry basis) in the sample; and $k$ : a constant whose value is 0.14 .

$$
[\eta]=\mathrm{k}(\mathrm{GP} v)^{\alpha}
$$

In which: $[\eta]$ : intrinsic viscosity; $\mathrm{k}$ and $\alpha$ : constants that depend on the solvent/polymer system. The ASTM D-4243 (ASTM INTERNATIONAL, 2009) Active Standard recommends the use of $\alpha=1$ and $\mathrm{k}=7.5 \times 10^{-}$ ${ }^{3}$ for the Kraft cellulose system in cupric ethylenediamine.

FLORESTA, Curitiba, PR, v. 49, n. 3, p. 411 - 420, jul/set 2019.

Silva, E. L. et.al.

ISSN eletrônico 1982-4688 


\section{Crystallinity Index}

The crystallinity index is an empirical method that uses focusing and transmission techniques, measuring the intensity of the interference in the 002 crystalline plane $\left(2 \theta=22^{\circ}\right)$ and the amorphous scatter at $2 \theta=18^{\circ}$. To determine the crystalline structure, the Shimadzu X-ray Diffractometer model XRD-7000 was used, along with the XRD-6100/7000 v5.0 software. A scanning speed of $2^{\circ} / \mathrm{min}$ varying from $5^{\circ}$ to $40^{\circ}$ was adopted, using $\mathrm{Cu}-\mathrm{K} \alpha$ radiation with a $1.5418 \AA$ wavelength and a voltage of $40 \mathrm{kV}$ with current of $20 \mathrm{~mA}$. This method - adopted for the determination of the crystallinity indexes - is suggested by Segal et al. (1959). In this method, the crystalline cellulose percentage $\left(\mathrm{I}_{\mathrm{Cr}}\right)$ is determined by the relationship between the intensity of the crystalline peak and the intensity of the amorphous portion:

$$
I_{C r}=\left(\frac{I 002-I a m}{I 002}\right) * 100
$$

In which: $I_{C r}$ : crystallinity index, $I_{a m}$ : diffraction intensity of the amorphous portion; and $I_{002}$ : peak diffraction intensity of the crystalline portion of plane 002 .

\section{RESULTS}

\section{Morphological characterization}

Figure 1A shows the Scanning Electron Microscopy image of the original cellulose pulp sample, and Figure 1B illustrates the appearance of this material prior to the mechanical defibrillation process. The cellulose fibers analyzed presented width of $11.4 \mu \mathrm{m}$ with deviation of $\pm 0.61 \mu \mathrm{m}$ and a homogeneous distribution. After mechanical treatment, the nanofibrillated cellulose samples showed a visible change in their physical appearance (Figure 1C). The homogeneity of the material increased in proportion to the number of passes through the grinder.
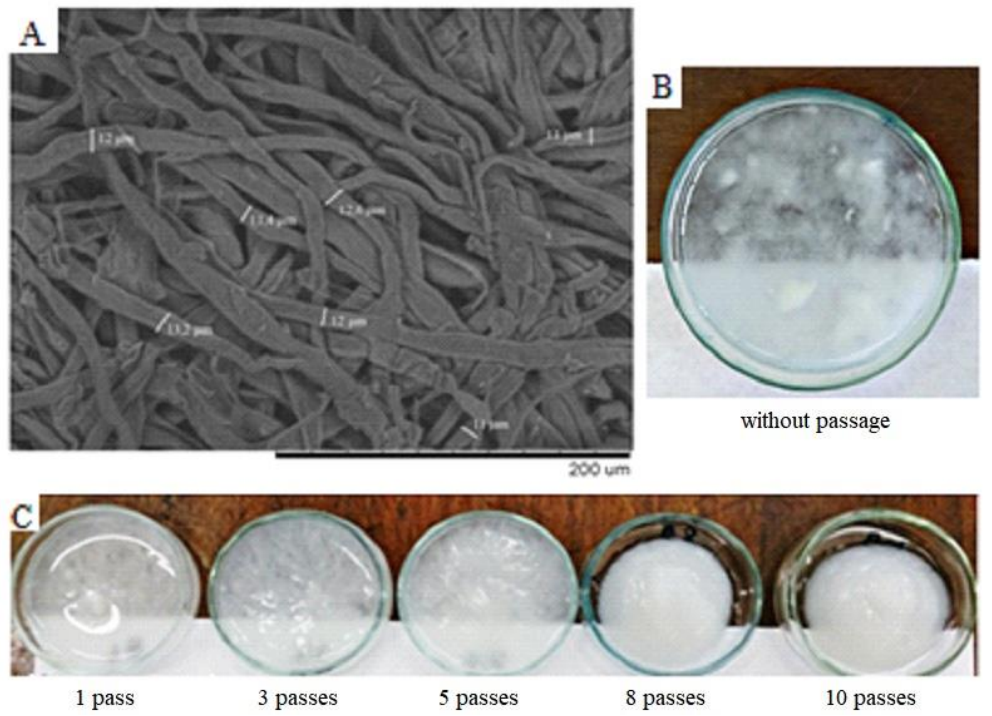

Figura 1. Imagens da polpa celulósica original (A e B) e CNF após o processamento mecânico nas diferentes passagens $(\mathrm{C})$.

Figure 1. Images of the original cellulose pulp (A and B) and of the NFC after the respective passes through mechanical treatment $(\mathrm{C})$.

A larger detail of nanostructures was verified by using the Atomic Force Microscopy (Figure 2A) and Transmission Electron Microscopy (Figures 2B-E) methods. The thickness of the nanofibrils was measured with mean of $19.5 \mathrm{~nm}$ and deviation of $\pm 12.11 \mathrm{~nm}$ (Figures 2C, D and E). 


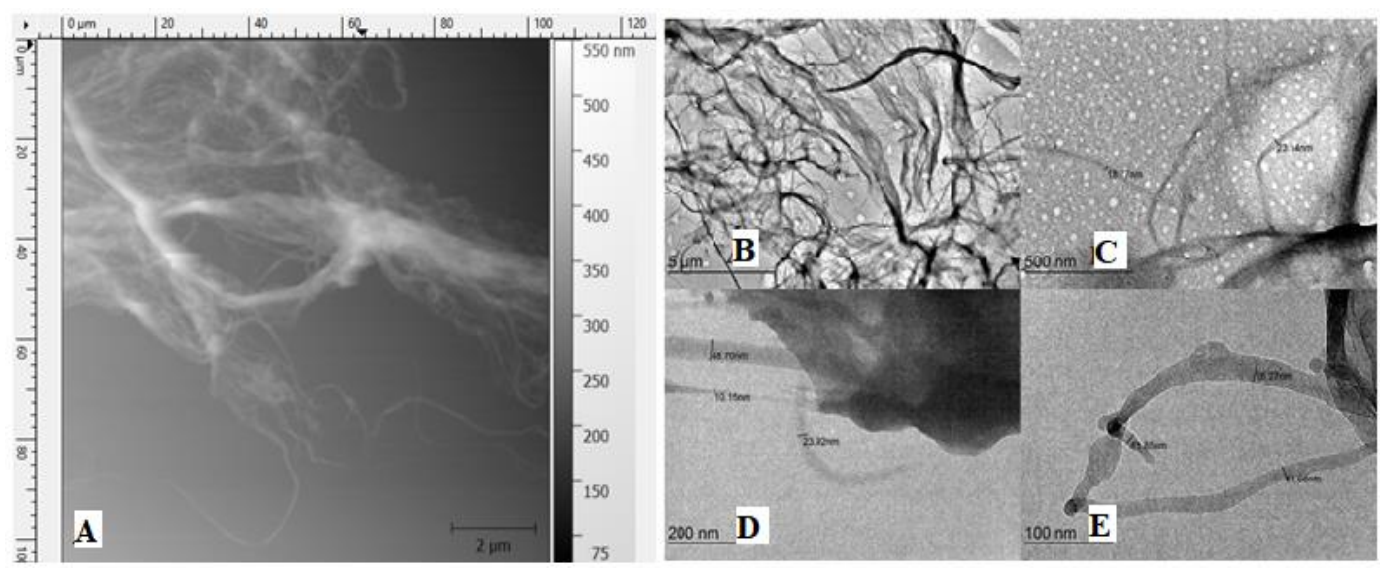

Figura 2. Imagens para CNF da análise por AFM aumento 2000x (A), e obtidas por MET: Vista geral da amostra com aumento de 1500x (B); detalhes em 3000x (C), 30000x (D) e 60000x (E).

Figure 2. NFC images of AFM analysis at 2000 times magnification (A), obtained by TEM: sample overview at 1500 times magnification (B); details at 3000 times (C), at 30000 times (D) and at 60000 times (E).

\section{Chemical and Thermal Characterization}

Analysis by Fourier transform infrared (FTIR) spectroscopy

FTIR spectra of the original cellulose and of NFC are shown in Figure 3.

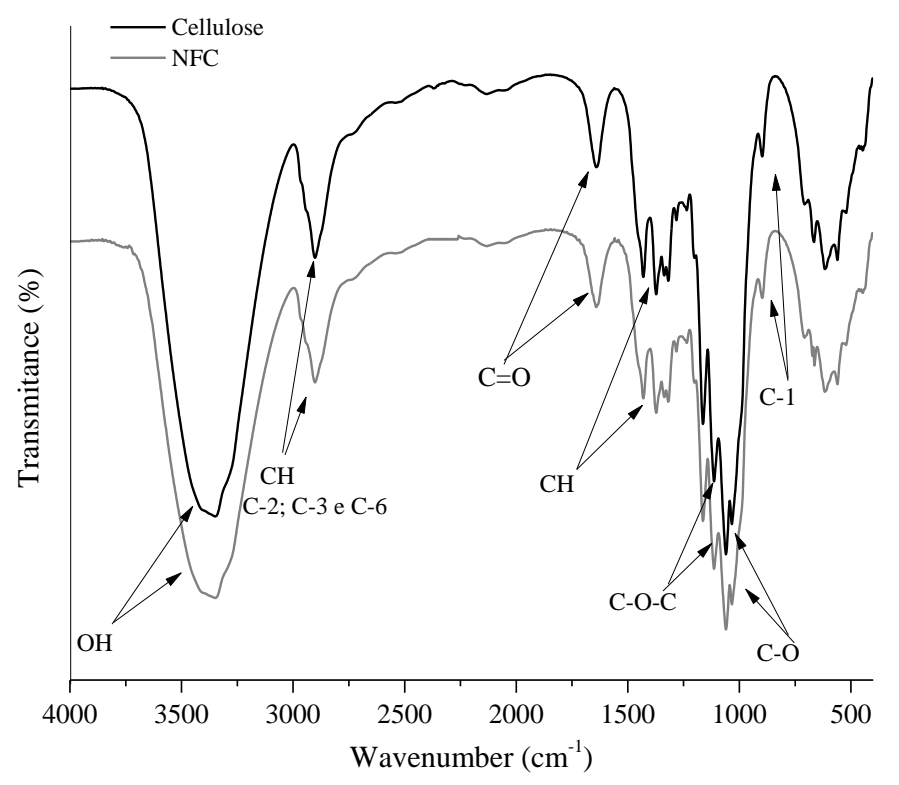

Figura 3. Espectro de FTIR das fibras de celulose antes (A) e CNF após o processamento mecânico (B). Figure 3. FTIR spectrum of the cellulose fibers before (A) and NFC after mechanical treatment (B).

\section{Thermogravimetric Analysis (TGA)}

Figure 4 shows the results of the thermogravimetric analysis of the cellulose fibers before and after the mechanical treatment. In both samples, two events of mass loss were observed. 

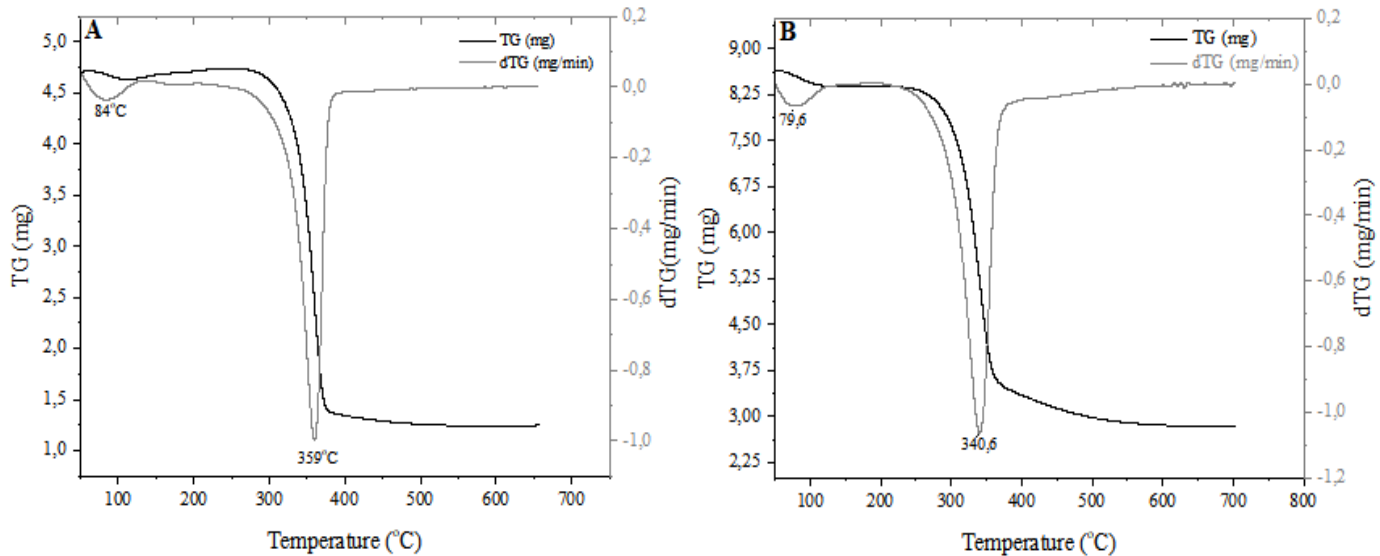

Figura 4. Termogramas obtidos para as amostras de celulose (A) e celulose nanofibrilada (B).

Figure 4. Thermograms obtained for the cellulose (A) and for the nanofibrillated cellulose (B) samples.

\section{Rheological Characterization and Crystallinity}

Viscosity and Degree of Polymerization

The mechanical fibrillation was responsible for the viscosity and DP variation in the sample, when compared to the original material (Table 1).

Tabela 1. Resultados de viscosidade e GP do material original e após cada passagem no moinho.

Table 1. Viscosity and DP of the original material and after each pass through the grinder.

\begin{tabular}{ccccc}
\hline Pass & $\begin{array}{c}\text { Specific viscosity } \\
\text { (mPa.s) }\end{array}$ & ${\text { Viscosity for } \mathbf{c}^{*}}^{*}$ & Intrinsic viscosity $^{\text {Degree of }}$ & $\begin{array}{c}\text { Dolymerization } \\
\text { polym }\end{array}$ \\
\hline 0 & $7.29 \mathrm{f}$ & $2.88 \mathrm{f}$ & $5.71 \mathrm{e}$ & $2410 \mathrm{e}$ \\
1 & $3.69 \mathrm{a}$ & $1.96 \mathrm{a}$ & $3.90 \mathrm{a}$ & $1643 \mathrm{a}$ \\
3 & $3.82 \mathrm{~b}$ & $2.00 \mathrm{~b}$ & $4.56 \mathrm{~d}$ & $1923 \mathrm{~d}$ \\
5 & $4.69 \mathrm{c}$ & $2.26 \mathrm{c}$ & $4.37 \mathrm{c}$ & $1844 \mathrm{c}$ \\
8 & $5.06 \mathrm{~d}$ & $2.37 \mathrm{~d}$ & $4.25 \mathrm{~b}$ & $1793 \mathrm{~b}$ \\
10 & $5.34 \mathrm{e}$ & $2.43 \mathrm{e}$ & $4.37 \mathrm{c}$ & $1842 \mathrm{c}$ \\
\hline
\end{tabular}

${ }^{*}$ According to $\mathrm{c}$ values in (ASTM INTERNATIONAL, 2009). Letters next to the numbers indicate that these values are statistically different from each other in the Tukey test (95\% of confidence).

\section{X-ray diffraction (XRD)}

By using X-ray diffraction, as indicated by Segal et al. (1959), it was possible to calculate the crystallinity index of the cellulose before and after the mechanical treatment. This index varied with the number of passes through the grinder. The results are shown in Figure 5.
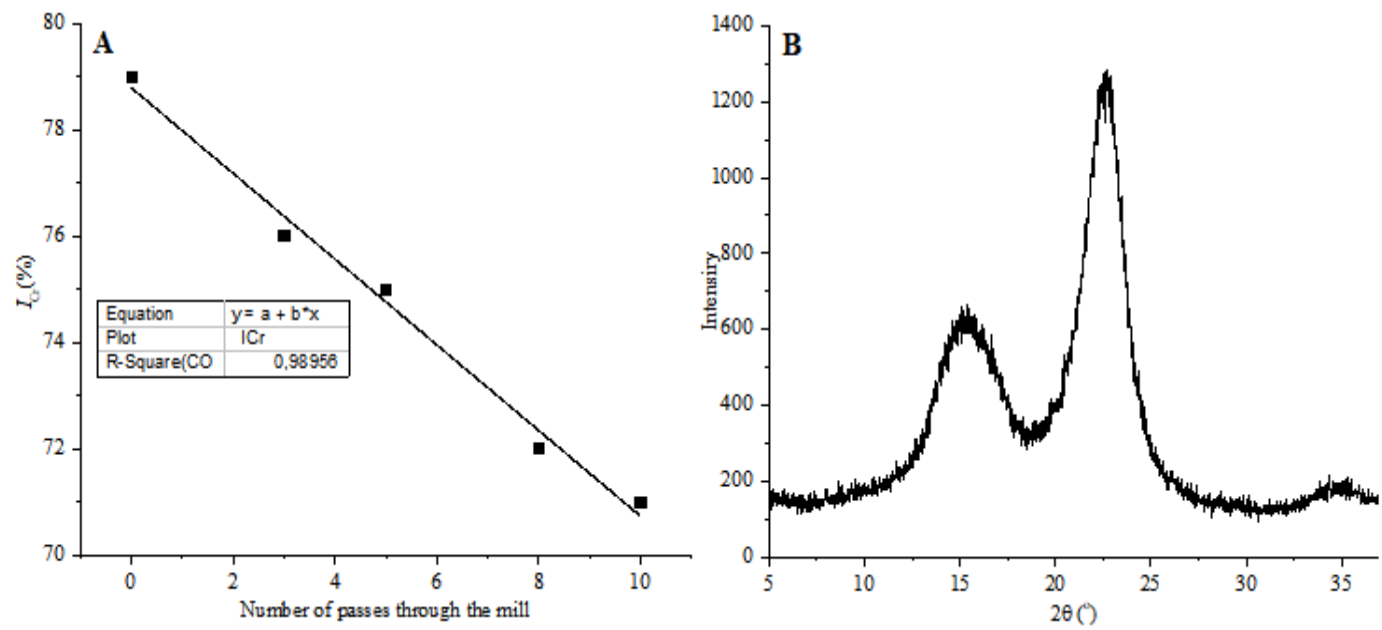

FLORESTA, Curitiba, PR, v. 49, n. 3, p. 411 - 420, jul/set 2019 
Figura 5. Variação no índice de cristalinidade para a celulose de acordo com o processamento mecânico (A) e Perfil do difratograma de Raios X para as amostras analisadas (B).

Figure 5. Variation in the crystallinity index of the cellulose according to the mechanical treatment (A) and X-ray diffraction profile for the analyzed samples (B).

\section{DISCUSSION}

\section{Morphological characterization}

The width of the cellulose fibers measured a mean of $11.4 \mu \mathrm{m}( \pm 0.61 \mu \mathrm{m})$, which is consistent with the mean typically found in literature (SILVA et al., 2007). After mechanical defibrillation, a visual change in the appearance of the material was observed, as well as a greater fibril/water and fiber/fiber interaction capacity through hydrogen bonds.

The AFM technique provides information on the exact topography of the nanostructures. As sample scanning occurs, valleys and peaks are defined as a function of the shape and organization of the nanofibrillated cellulose. The images obtained help in the evaluation of the material by showing properties of the NFC, such as nano-scale diameters and varied lengths. They also depict a formation of a nanostructure network, which differentiate the fibers from the original ones. Figure $2 \mathrm{~A}$ and $2 \mathrm{~B}$ show that the mechanical treatment on the cellulose pulp causes a fibrillation effect on the cell wall of the fibers, reducing their diameter and generating NFC, whose length is in micrometer scale and diameter in nano-scale, as studied by Coutts (2005).

Since cellulose is considered nanofibrillated when one of its dimensions is below $100 \mathrm{~nm}$, it is concluded that the mechanical defibrillation treatment enabled the production of nano-scale material, as also observed by other authors (SEHAQUI et al., 2011; SYVERUD et al., 2011).

When occurring in the outer layers of the cell wall, defibrillation exposes the inner layers, reduces one of the cell wall dimensions and increases its contact area and its potential for bonds, thus forming a nanostructured network. In this sense, the three hydroxyl groups bonded to carbons 2, 3 and 6 of the glucose units in cellulose are responsible for the intermolecular interactions in the cellulose chain, allowing for new structures to be formed (HABIBI et al., 2007).

\section{Chemical and Thermal Characterization}

For the mid-infrared spectrometry analyses (Figure 3), the characteristics of cellulose were attributed for both samples: the intense and broad band in the region from 3500 to $3400 \mathrm{~cm}^{-1}$ corresponds to the absorption of $\mathrm{OH}$ groups; the signal near $2900 \mathrm{~cm}^{-1}$ represents the symmetrical stretching of $\mathrm{C}-\mathrm{H}$ bonds originating from $\mathrm{H}-\mathrm{C}$ $\mathrm{OH}$ (C-2 and C-3 carbon) and $\mathrm{CH}_{2} \mathrm{OH}$ (C-6 carbon) groups of the cellulose; the band in the region $1640 \mathrm{~cm}^{-1} \mathrm{can}^{-1}$ be attributed to the presence of conjugated carbonyls, which probably derived from the oxidation of carbohydrates during the bleaching process (FAN et al., 2012).

The bands around 1430 and $1370 \mathrm{~cm}^{-1}$ refer to the angular deformation of $\mathrm{C}-\mathrm{H}$ in the carbonic chain; absorption bands in 1330 and $1320 \mathrm{~cm}^{-1}$ correspond to the $\mathrm{OH}$ angular vibrations of primary and secondary alcohols; bands in 1165 and $1110 \mathrm{~cm}^{-1}$ are in this regions due to asymmetric axial deformations of C-O-C; bands from 1050 to $1030 \mathrm{~cm}^{-1}$ correspond to the axial deformations of $\mathrm{C}-\mathrm{O}$ in primary and secondary alcohols; and finally the deformation in $896 \mathrm{~cm}^{-1}$ is attributed to the anomeric carbon $\mathrm{C}-1$ of the anhydroglucose. Because it is a bleached pulp with low kappa number, no characteristic bands of lignin were observed in the cellulose spectrum in general, which justifies the qualitative character of the FTIR analysis (ASHORI et al., 2014).

As observed in both spectra, the samples behave in the same way. This evidence suggests that nanofibrillation of cellulose does not promote change in its carbon chain, which remains with the same supramolecular structure.

The thermograms of the cellulose pulp (Figure 4A) and nanofibrillated cellulose (Figure 4B) samples can be divided into three events, considering that the initial mass of the cellulose pulp was $4.5 \mathrm{mg}$. In the first event, from $45^{\circ} \mathrm{C}$ to $130^{\circ} \mathrm{C}$, the thermogram presented a small mass loss $(3 \%)$, which is attributed to desorption of water present in the fibers. In the second event, from $280{ }^{\circ} \mathrm{C}$ to $375^{\circ} \mathrm{C}$, with degradation peak at $359.6{ }^{\circ} \mathrm{C}$ and mass loss of $70 \%$, the crystalline region began to be destroyed. The decomposition of the sample was likewise noted, resulting in the increase of the amorphous portion and a decrease in the degree of polymerization. The third event occurs from $375^{\circ} \mathrm{C}$ up to the end of the analysis: it is when the crystalline region was completely destroyed and decomposed into D-glucopyranose monomer. This monomer, in turn, is decomposed into free radicals at higher temperatures (above $600{ }^{\circ} \mathrm{C}$ ). The complete process generated a mass loss of about $73 \%$, leaving a mass residual of approximately $1.24 \mathrm{mg}$.

FLORESTA, Curitiba, PR, v. 49, n. 3, p. 411 - 420, jul/set 2019.

Silva, E. L. et.al.

ISSN eletrônico 1982-4688

DOI: $10.5380 /$ rf.v49 i3.58864 
For the nanofibrillated cellulose, the decomposition process is the same, but with different temperatures for the thermal events. The initial sample mass was $8.56 \mathrm{mg}$. The first event is also related to the evaporation of the water present in the fibers, since it occurred from $79.6{ }^{\circ} \mathrm{C}$ to $130{ }^{\circ} \mathrm{C}$ and had a mass loss of $3 \%$. The second event occurs from $235{ }^{\circ} \mathrm{C}$ to $392{ }^{\circ} \mathrm{C}$, with degradation peak at $340.6{ }^{\circ} \mathrm{C}$ and mass loss of approximately $59 \%$ at this temperature. The total process generated a mass loss of approximately $62 \%$, and a residual mass of $2.84 \mathrm{mg}$.

The thermal degradation events are attributed to two main mechanisms: i) dehydration of the cellulose caused by an endothermic event; and ii) thermal depolymerization of the cellulose (NETO et al., 2013). From 392 ${ }^{\circ} \mathrm{C}$ onwards, the thermal decomposition of the cellulose in D-glucopyranose monomers starts, as well as its decomposition into free radicals (ASHORI et al., 2014).

The thermogravimetric curves are very similar, since NFC and cellulose have basically the same chemical composition. The initial temperature of the cellulose degradation $\left(280^{\circ} \mathrm{C}\right)$ was higher than the NFC's $\left(235^{\circ} \mathrm{C}\right)$. The decrease in the thermal stability of the natural fiber due to mechanical treatment has been described in literature and generally is related to the cellulose degradation resulted from the shear forces involved in the mechanical treatment (MTIBE et al., 2015; QING et al., 2013).

\section{Rheological Characterization and Crystallinity}

The results found for both viscosity and degree of polymerization (Table 1) after the mechanical treatment demonstrate the negative influence of this procedure on the integrity of the cellulose fiber. According to some studies, mechanical defibrillation treatment causes irreversible changes in the fibers, for example, reduction in crystallinity and viscosity resulted from internal and external fibrillation. Defibrillation exposes the inner layers, reducing the size of the fibers, which facilitates the formation of inter and intra fibrillary interactions, forming a nanostructured network (COUTTS, 2005; WANG et al., 2012; KHALIL, 2014).

Thus, a decrease in the viscosity and in the DP of the cellulose was observed in relation to the initial sample (which did not pass through the grinder). When comparing the viscosity and DP results of the samples treated mechanically, a variation in both properties was observed (Table 1), which demonstrates the influence of mechanical treatment on the integrity of the material.

During the first passes (1 and 3) through the grinder, there was a sharp decrease in the rheological properties of the samples. As the number of passes through the grinder increased, as well as the formation of fibrils, the inter- and intra- fibrillary attraction forces were capable of exerting an effect that minimizes the mechanical degradation observed in the initial stages of the process. This effect may be due to the increase in the aspect ratio, in the contact area between the fibrils surface, and in the iterations and interweaving of the nanofibrils, generating a kind of resistant nanofibrillar net that enables these interactions and maintains the characteristics of viscosity and DP very similar in the treated samples (5, 8 and 10). This observation indicates that the formation of nanofibrils influences the pulp properties, which becomes a material of peculiar and desirable characteristics for the development of new products.

Because of the mechanical action, the material defibrillates, as observed in the micrographs shown in Figures 1 and 2. This behavior is probably responsible for the decrease in the DP and in the viscosity of the cellulose in relation to the initial material, since it generates cellulose chains of varying sizes. The reduction in the cellulose viscosity after mechanical defibrillation treatment was also observed by some authors (WANG et al., 2012).

When the number of passes through the grinder increases, the crystallinity index or the beginning of the degradation of the crystalline portion decreases, as a function of the shear forces involved in the process. The internal and external defibrillation of the fiber is the cause of the reduction in the dimensions of the fibers, in addition to affecting its crystallinity The X-ray diffractogram of the cellulose shows a peak in the region $2 \theta$ of $15^{\circ} \mathrm{C}$ (little intense) and a more intense one in the region $2 \theta$ of $22{ }^{\circ} \mathrm{C}$ (Figure 5B), which represent the crystal planes for both cellulose fibers and nanofibrillated cellulose. The reduced crystallinity of the cellulose after treatment may be the property responsible for the decrease in the thermal stability of the viscosity and DP of this material, since this is the portion of the cellulose fiber that suffers the mechanical action of the grinder, as observed by other authors (KALIA et al., 2014; WANG et al., 2012; COUTTS, 2005).

Therefore, the values found for the cellulose crystallinity in this study are similar to those expected and suggested by previous studies. Regarding nanofibrillated cellulose, there is practically no variation in the crystallinity indexes. However, there is a tendency of reduction in relation to the initial value, which has been also observed in the literature (KALIA et al., 2014). 


\section{CONCLUSION}

- The mechanical defibrillation treatment of the cellulose was sufficient to generate fibrils of nanometric dimensions in thickness.

- The nanofibrillated cellulose suspension is much more homogeneous than the initial fiber suspension, because the surface area of the nanofibrils is much larger. This property provides much more stability through the possible hydrogen bonds.

- The nanofibrillated material showed different responses in relation to the initial material. In addition to the dimensions, the thermal stability, crystallinity, viscosity and DP presented lower values than the original material.

- The reduced crystallinity of the cellulose after treatment may be the property responsible for the decrease in the thermal stability of the viscosity and DP of this material, since this is the portion of the cellulose fiber that suffers the mechanical action of the grinder.

- As surface area increases, the number of reactive points on the surface increases, which can be used in derivatization reactions or in the basis of other compounds of interest, thus, providing a range of options for the production of new materials.

\section{ACKNOWLEDGEMENTS}

The authors would like to thank the Federal University of Paraná for the infrastructure, the Microscopy Center (CEM) - UFPR for the Transmission Electron Microscopy and Atomic Force Microscopy analyses, the Physics Department - UFPR for the X-ray Diffractometer; The Academic Publishing Advisory Center (Centro de Assessoria de Publicação Acadêmica, CAPA - www.capa.ufpr.br) of the Federal University of Paraná for assistance with English language editing. This study was financed in part by the Coordenação de Aperfeiçoamento de Pessoal de Nível Superior - Brasil (CAPES) - Finance Code 001.

\section{REFERENCES}

ASHORI A; BABAEE M; JONOOBI M; HAMZEH Y. Solvent-free acetylation of cellulose nanofibers for improving compatibility and dispersion. Carbohydrate Polymers, (Worcester), v. 102, p. 369-375, 2014.

ASTM INTERNATIONAL. ASTMD-4243-16 - Standard test method for measurement of average viscometric degree of polymerization of new and aged electrical papers. (West Conshohocken), 2009.

CORREIA, VC ; DOS SANTOS, V; SAIN, M; SANTOS, SF; LEÃO, AL; SAVASTANO JUNIOR, H., Grinding process for the production of nanofibrillated cellulose based on unbleached and bleached bamboo organosolv pulp. Cellulose, (New Orleans), v. 23, p. 2971-2987, 2016

COUTTS RSP. A review of Australian research into natural fibre cement composites. Cement and Concrete Composites, (British Columbia), v. 27, p. 518-526, 2005.

DEEPA B; ABRAHAM E; CORDEIRO N; MOZETIC M; MATHEW AP.; OKSMAN K; FARIA M; THOMAS $\mathrm{S}$; POTHAN LA. Utilization of various lignocellulosic biomass for the production of nanocellulose: a comparative study. Cellulose, (New Orleans), v. 22, n. 2, p. 1075-1090, 2015.

FAN M, DAI D; HUANG B. Fourier Transform Infrared Spectroscopy for Natural Fibres. In: DR SALIH SALIH (ed) Fourier Transform - Materials. Analytical Intech Europe, (London), p. 45-68, 2012.

HABIBI Y; FOULON L; AGUIÉ-BÉGHIN V; MOLINARI M; DOUILLARD R. Langmuir-Blodgett films of cellulose nanocrystals: Preparation and characterization. Journal of Colloid and Interface Science, (Copenhagen), v. 316, p. 388-397, 2007.

KALIA S; BOUFI S; CELLI A; KANGO S. Nanofibrillated cellulose: Surface modification and potential applications. Colloid and Polymer Science, (Köln), v. 292, p. 5-31, 2014.

KHALIL, AHPS, DAVOUDPOUR Y, ISLAM MN, MUSTAPHA A, SUDESH K, DUNGANI R, JAWAID M. Production and modification of nanofibrillated cellulose using various mechanical processes: a rewiew. Carbohydrate Polymers (Worcester), v. 99, p. 649-665, 2014.

FLORESTA, Curitiba, PR, v. 49, n. 3, p. 411 - 420, jul/set 2019.

Silva, E. L. et.al.

ISSN eletrônico 1982-4688 
LAVOINE, N.; DESLOGES, I., BRAS, J., Microfibrillated cellulose coatings as new release systems for active packaging. Carbohydrate Polymers, (Woscester), v. 103, p. 528- 537, 2014.

MOON DM; SUKAHARA KT; AGISAKA MS; AHARA KT. Effect of Cellulose Nanofibers Composites in Automotive Components on Greenhouse Gas Emissions. Journal of the Japan Institute of Energy, v. 95, p. 648-652, 2016.

MTIBE A; LINGANISO LZ; MATHEW AP; OKSMAN, K; JOHN MJ; ANANDJIWALA RD.A comparative study on properties of micro and nanopapers produced from cellulose and cellulose nanofibres. Carbohydrate Polymers, (Worcester), v. 118, p. 1-8, 2015.

MUÑIZ, G. I. B.; CORADIN, V. R. Normas de procedimentos em estudo de anatomia da Madeira. I Angiospermae, II - Gimnospermae. Brasília: Laboratório de Produtos Florestais. Série Técnica. n. 15, 1992.

NETO, WPF; SILVÉRIO, HA, DANTAS, NO, PASQUINI, D. Extraction and characterization of cellulose nanocrystals from agro-industrial residue - Soy hulls Wilson Pires Flauzin. Industrial Crops and Products, (St Martin d'Heres), 42, p. 480-488, 2013.

OKIYAMA A; MOTOKI M; YAMANAKA S. Bacterial Cellulose IV. Application to Processed Foods. Food Hydrocolloids, (Wrexham) v. 6, p. 503-511, 1993.

QING Y; SABO R; ZHU JY; AGARWAL U; CAI Z; WU Y. A comparative study of cellulose nanofibrils disintegrated via multiple processing approaches. Carbohydrate Polymers, (Worcester), 97, p. 226-234, 2013.

SACUI IA, NIEUWENDAAL RC, BURNETT DJ, STRANICK SJ, JORFI M, WEDER C, FOSTER EJ, OLSSON RT, GILMAN JW Comparison of the properties of cellulose nanocrystals and cellulose nanofibrils isolated from bacteria, tunicate, and wood processed using acid, enzymatic, mechanical, and oxidative methods. ACS Applied Materials Interfaces (San Antonio) v. 6, p. 6127-6138, 2014.

SEGAL L; CREELY JJ; MARTIN AE; CONRAD CM. An Empirical Method for Estimating the Degree of Crystallinity of Native Cellulose Using the X-Ray Diffractometer. Textile Research Journal, (Clarksville), v. 29, p. 786-794, 1959.

SEHAQUI H; ZHOU Q; BERGLUND LA. High-porosity aerogels of high specific surface area prepared from nanofibrillated cellulose (NFC). Composites Science and Technology, (Newark), v. 71, p. 1593-1599, 2011.

SILVA, JC; TOMAZELLO FILHO, M; OLIVEIRA, JTS; CASTRO, VR. Influência da idade e da posição radial nas dimensões das Fibras e dos vasos da madeira de Eucalyptus grandis hill ex. Maiden ${ }^{1}$. Revista Árvore, (Viçosa), v. 31, n. 6, p. 1081-1090, 2007.

SOUZA, S. F.; Leao, A. L. ; CAI, J. H. ; WU, C. ; SAIN, M. ; CHERIAN, B. M. . Nanocellulose from Curava Fibers and their Nanocomposites. Molecular Crystals and Liquid Crystals (Philadelphia), v. 522, p. 4252, 2010.

SYVERUD K; CHINGA-CARRASCO G; TOLEDO J; TOLEDO PG. A comparative study of Eucalyptus sp and Pinus radiata pulp fibres as raw materials for production of cellulose nanofibrils. Carbohydrate Polymers, (Worcester), v. 84, p. 1033-1038, 2011.

TONOLI GHD; TEIXEIRA EM; CORRÊA AC; MARCONCINI JM; CAIXETA LA; PEREIRA-DA-SILVA MA; MATTOSO LHC. Cellulose micro/nanofibres from Eucalyptus kraft pulp: Preparation and properties. Carbohydrate Polymers, (Worcester), v. 89, p. 80-88, 2012.

VILLANOVA JC, AYRES E, CARVALHO SM, PATRÍCIO PS, PEREIRA FV, ORÉFICE RL. Pharmaceutical acrylic beads obtained by suspension polymerization containing cellulose nanowhiskers as excipient for drug delivery. European Journal of Pharmaceutical Sciences, (Odense), v. 42, p. 406-415, 2011.

WANG QQ; ZHU JY; GLEISNER R.; KUSTER TA; BAXA U; MCNEIL SE. Morphological development of cellulose fibrils of a bleached eucalyptus pulp by mechanical fibrillation. Cellulose, (New Orleans), v. 19, p. 1631-1643, 2012. 